\title{
Chapter 1 \\ INTRODUCTION \\ TO MACROECONOMIC \\ ACCOUNTS, ANALYSIS, AND \\ RELATED POLICY ISSUES
}

Macroeconomics is the study of an entire economy. Macroeconomics assumes the existence of many individual economic sectors and the markets governing them. Thus, the focus is on the behavior of the economy as a whole - the aggregate of all the markets for goods and services, as well as the impact of the public sector (government and government-owned entities, called public or state-owned enterprises) and the rest of the world on the economy. Studying an entire economy requires conceiving of aggregate demand - the total demand for goods and services in the economy — and aggregate supply — the total amount of goods and services made available for sale in the economy. In equilibrium, aggregate demand and aggregate supply should be equal. In practice, aggregate demand and supply can differ, generating a variety of macroeconomic conditions, including short- to medium-term fluctuations in an economy, called business cycles.

Macroeconomic analysis involves studying an economy's main components. These include

- The main sectors of the economy and relevant information about them, recorded in various sectoral accounts; 
- Important indicators of macroeconomic performance, representing key variables drawn from the various sectoral accounts; and

- The principal policies used to achieve broad objectives for the economy, typically high rates of economic growth, macroeconomic stability (meaning low inflation), a sustainable external position, and various other objectives, such as low poverty rates, an acceptable distribution of income and wealth, and a safe and sustainable physical environment.

Although each economy has particular sectors of special importance the petroleum sector, for example, in Saudi Arabia, or the tourist sector in Maldives or Barbados - for purposes of analysis, it is useful to view every economy as having four broad economic sectors, each with its own set of economic accounts. These sectors and their principal accounts are as follows:

1. The real sector, often called the national accounts. The real sector comprises production and expenditure in the economy. Its accounts measure the total activity in the economy, described either from the standpoint of production, expenditure, or income. The real sector also records data on inflation in the economy, using such measures as a consumer price index, other price indices, and a price index for overall output or expenditure called the gross domestic product (GDP) deflator. Chapter 2 provides an extensive discussion of the accounts and performance indicators in the real sector.

2. The external sector. The external sector covers the relations between the economy and the rest of the world. The economic aspects of these relations are recorded in a set of accounts called the balance of payments. The balance of payments records in detail the amount of trade in goods and services between the economy and other economies. It also shows income, capital, and financial interactions between the economy and the rest of the world, as well as changes in the amount of an economy's official reserves (the stock of gold, foreign exchange, and similar assets held by the country's monetary authority or central bank). The accounts of the external sector also record a country's stock of foreign debt and debt service, including payments of both interest and principal (amortization). 
Besides the balance of payments and debt, data for the external sector will typically include indicators of the economy's competitiveness, including data on the country's exchange rate.

3. The fiscal sector. The fiscal sector involves the activities of government and government-owned non-financial entities called public or stateowned enterprises. (Publicly owned financial entities are covered in the monetary sector, described below.) The government sector's financial activities are usually recorded in the fiscal accounts of the government sector, typically in a comprehensive budget for the entire sector or for different levels of government (where there are separate budgets for the central and sub-national units of government). There may also be data on the consolidated public enterprise sector — total income, expenses, profits or losses, and any financing needed to cover losses. As with the external sector, fiscal data also include information on government and stateenterprise debt and debt service.

4. The monetary sector. The monetary sector comprises the activities of the economy's financial institutions, including its central bank or monetary authority, the commercial (deposit money) banks, and other financial institutions, such as investment banks, finance companies, credit unions, and any microfinance entities. The activities of the main part of the financial sector, the banking system, which comprises the monetary authority and the commercial banks, are recorded in a set of monetary accounts. The accounts record the assets and liabilities of the various institutions covered.

\section{AN OVERVIEW OF THE ACCOUNTS AND KEY PERFORMANCE INDICATORS FOR EACH SECTOR}

1. The real sector. The accounts of the real sector record developments in an economy's income and prices. The accounts for income (which may also record total value added or total expenditure in the economy) represent flows, meaning activities that occur during a period of time, such as a year, as opposed to quantities of goods or services at a single point in time. The income (or production or expenditure) accounts of the real sector are measured both in nominal terms (meaning at current prices) and 
in real terms (meaning at a constant set of prices). If measured in real terms, these accounts allow comparison of the true volumes or amounts of goods and services produced, or expenditure made, or income earned, from one period to another. Key indicators of real sector performance include the growth (percent change) in real GDP; the output gap or unemployment rate; the ratios of gross investment and gross saving to GDP; and the rates of change in the consumer price index and other price indices.

2. The external sector. The accounts of the external sector focus on developments in the balance of payments, external debt, and external debt service, along with the composition and direction of trade (both exports and imports, particularly of goods). Except for the stock of external debt, the accounts record flows, since trade, financial flows, and debt service involve funds received or paid out during a period of time. The accounts of the external sector are typically recorded in nominal terms (at current prices) and are often presented both in domestic currency and in a commonly used foreign currency, such as euros or U.S. dollars. Key indicators of external sector performance include the current account balance in the balance of payments as a percent of GDP; the overall balance in the balance of payments and the level of gross official reserves; the ratios of gross reserves to imports (measured in months of imports) and to shortterm debt (debt service due during the coming 12 months); the stock of external debt as a percent of GDP and the amount of debt service as a percent of export earnings (usually of goods and services); and competitiveness measures such as the change in the real exchange rate.

3. The fiscal sector. The accounts of the fiscal sector record developments in the government's financial interactions with the rest of the economy and the rest of the world. They may also include developments in the consolidated set of public enterprises. Except for stocks of government and public sector debt, the accounts record flows, since items such as revenues, expenditures, and budget financing entail funds received or paid over a period of time. The fiscal accounts are measured in nominal terms (current prices), although fiscal data are often also reported in percentages of GDP, to allow comparison across years (and with other economies' data). A comprehensive view of the fiscal sector includes not only the accounts of the central 
(national) government, but also the consolidated accounts of any state or provincial governments and, if available, of local governments. Including the consolidated accounts of the public (state-owned) enterprises shows the position of the overall public sector. Key indicators of fiscal sector performance include the overall balance of the central and general (consolidated) government budget as a percent of GDP; total revenues and expenditures as percentages of GDP, ideally with breakdowns of revenue into tax and non-tax receipts and expenditure into current and capital expenditure or expense and net acquisition of non-financial assets (again as percentages of GDP); the buoyancy (elasticity) of total revenue and tax revenue to GDP, which shows whether these items keep pace with the growth of nominal GDP; and the ratios of government and public sector debt to GDP.

4. The monetary sector. The accounts of the monetary sector show developments in the main financial institutions of an economy, typically focusing on the banking system, which usually represents the bulk of the financial system. Because the accounts record assets and liabilities of different institutions or groups of institutions at a point in time, they record stocks, rather than flows. However, flows in the monetary sector can be constructed by calculating changes in these stocks during a time period. Monetary accounts are recorded in domestic currency, in nominal terms (current prices). As a result, the domestic currency value of foreign currency items, such as international reserves and foreign exchange deposits, can change as the exchange rate fluctuates. Important measures of monetary sector performance include the growth rate of broad money and its main components (e.g., broad money in domestic currency); nominal and real interest rates on loans and deposits; the percentage of loans considered non-performing (i.e., seriously delinquent); the growth in real credit to the private sector (after adjusting for changes in the price level over time); measures of household and corporate debt; and indices of equity (stock) and house prices, which may be useful for identifying asset "bubbles" (price increases to unsustainable levels, far beyond what fundamentals would justify).

\section{LINKAGES AMONG SECTORS}

The four main economic sectors are related in a variety of ways. Developments in one sector affect other sectors, and policies aimed at one 
sector (for example, changes in fiscal policy) inevitably affect most sectors. For example, a rise in the population's desire to consume, which increases aggregate demand and total private expenditure (real sector variables), typically raises government revenues, through higher sales or value-added tax collections, thus affecting the fiscal sector. Higher consumption may also boost imports, affecting the external sector (balance of payments). Higher consumption could mean an initial decline in household deposits and/or a rise in consumer loans, affecting the monetary accounts. Thus, a change originating in the real sector spreads to other sectors.

Changes originating in other sectors also affect other sectors. A rise in government pension payments will boost income, and most likely consumer expenditure, thus affecting the real sector. Higher pensions would probably raise imports, affecting the balance of payments. In addition, a rise in government pensions should mean at least an initial rise in household deposits, probably followed by increases in business deposits, thereby affecting the monetary accounts. Depreciation of the exchange rate typically reduces imports, at least over time, and may also boost exports, as competitiveness increases, thereby affecting the trade balance and current account of the balance of payments (external sector). Lower imports would reduce customs (import) duties, thereby affecting the government budget (fiscal accounts), while a stronger current account balance would likely raise international reserves, thereby affecting the monetary sector. Finally, relaxing monetary policy, by cutting the central bank's policy interest rate, will likely expand lending, thereby affecting the monetary sector. Higher lending, whether for consumption or investment, should add to economic growth and income, thereby affecting the real sector. Moreover, higher investment may lead to more imports of investment (capital) goods, thereby affecting the balance of payments.

\section{MACROECONOMIC OBJECTIVES AND POLICIES TO ATTAIN THEM}

As mentioned earlier, economies typically aim at achieving certain broad macroeconomic objectives designed to deliver a high or improved standard living for citizens or residents. Attaining a high standard of living typically requires an acceptable rate of real economic growth, sufficient to raise per 
capita income and to provide enough jobs to keep the unemployment rate low. ${ }^{1}$ A well-performing economy also attains relative price stability (low inflation $)^{2}$ and a "sustainable" external position, meaning a balance of payments that can be maintained without need for a major change in exchange rate or trade policy and that does not lead to high ratios of external debt to GDP. Finally, most economies are concerned not only about the average level of income per capita but also about in its distribution. Thus, economies typically aim at reducing the percentage of people in poverty, and many also try to reduce income inequality by providing benefits targeted at low- to middle-income households and, in some cases, imposing higher taxes on upper-income households and the wealthy. As noted earlier, many countries also enact policies aimed at achieving other broad economic objectives, such as reducing pollution or improving the physical environment.

Considerable history suggests that achieving price stability and a sustainable external position are important for being able to sustain growth. Countries like Turkey, which for many years before 2000 experienced high inflation, had trouble keeping growth rates high so long as prices were elevated. In the case of Turkey, a few years of moderate (3-5 percent) real growth was frequently followed by an economic collapse, as the failure of the exchange rate to offset inflation led to a loss of competitiveness and an inability to finance imports and external debt. Similarly Romania, where inflation exceeded 300 percent early in the 1990s, experienced poor growth until inflation fell to more reasonable levels. More generally, many researchers have found that, above a minimum level (perhaps 1-3 percent for advanced economies and somewhat higher rates for developing and emerging market countries), higher inflation corresponds with lower growth rates. ${ }^{3}$ One reason may be that higher inflation discourages private investment, encourages

\footnotetext{
${ }^{1}$ An economy's unemployment rate measures the ratio of those looking but unable to find work to those in the labor force. The unemployment rate can fluctuate not only with changes in the level of employment but also with changes in the number of those seeking work, as people enter or leave the labor force.

${ }^{2}$ Most economies aim at a low, rather than zero, rate of inflation, to allow increases in wages and prices to help attract resources to expanding sectors. These increases, averaged across the economy, result in small amounts of inflation.

${ }^{3}$ See, for example, Khan, M., and A. Senhadji (2001), "Threshold Effects in the Relationship Between Inflation and Growth," IMF Staff Papers, Vol. 48, No. 1, pp. 1-21 (December).
} 
inefficient activities aimed at preserving the value of financial assets, and promotes capital flight to other economies with less inflation or a shift in assets to more stable currencies. As for external stability, balance of payments crises have imposed huge economic losses on many countries at all levels of economic development. In Asia, Indonesia, Malaysia, Thailand, and the Republic of Korea all suffered major declines in real GDP during 1998 because of large capital outflows (although Korea's situation stabilized within a year after short-term loans were renewed). Real GDP fell nearly 11 percent in Argentina during 2002 after continuing fiscal imbalances and an end to International Monetary Fund (IMF) support forced the country to abandon pegging its exchange rate to the U.S. dollar. In 2009 Iceland's real GDP fell nearly 7 percent, as huge losses in the banking sector triggered a collapse in the krona and a sharp decline in real imports and consumption.

Attaining attractive growth rates, low inflation, and a sustainable balance of payments requires a skilled mix of well-coordinated macroeconomic policies. These include

- Monetary policy (the choice and level of the monetary policy instrument, typically an overnight interest rate, along with the type of monetary framework and level of reserve requirements);

- Fiscal policy (the level and composition of revenues and expenditures, the level of budget balance or deficit, and the composition of budget financing);

- Exchange rate policy (the choice of exchange rate regime and policies affecting the level of the real exchange rate); and

- Structural policies (a wide array of specific measures involving trade, labor, competition, financial sector regulation, pricing, state enterprises, and governance, many of which affect the economy's investment climate). In recent years, financial sector regulation has become especially important, as banking crises have led to severe recessions in many economies, including Iceland, Ireland, Mexico, Spain, the United Kingdom, and the United States, with regional and even global spillovers, particularly after the U.S. financial crisis starting in late 2007.

Experience has shown that certain policies are critical for attaining and preserving macroeconomic stability (low inflation and a sustainable balance of payments). These include 
- Monetary policy focused on attaining low inflation;

- Fiscal policy (in particular a level of the government budget deficit) that limits the demand for government financing and maintains a low to moderate ratio of public debt to GDP;

- An exchange rate regime appropriate for the economy (this will depend on the economy's circumstances, including the composition of its trade) that attains and maintains a competitive real exchange rate; and

- Supporting structural policies that provide an attractive investment climate; assist monetary, fiscal, and exchange rate policy; and foster public support for macroeconomic stability.

Experience has also shown that certain policies are essential for promoting economic growth. ${ }^{4}$ These include attaining and maintaining macroeconomic stability, along with implementing various growth-promoting policies. Countries with sustained high growth rates have typically achieved low inflation and a strong balance of payments; attained high rates of investment and national savings, including reasonable rates of public investment; used markets and market prices to allocate most economic resources; achieved close integration with the world economy through liberal trade policies; established strong governance; and focused policies on promoting growth. Following from the above list, countries with high growth rates have typically developed and maintained good physical infrastructure, including reliable transport systems and sources of electricity. They have also developed strong and effective institutions, including the rule of law and respect for private property; an effective and impartial judicial system; an effective and stable financial system; an education system that produces graduates well prepared to fill job openings in the economy; political stability and good governance (effective and honest political administration); and a fiscal environment able to respond to new challenges. Together, these and related features, such as the ability to resolve insolvency effectively, relative simplicity in paying taxes, and

\footnotetext{
${ }^{4}$ For a comprehensive analysis of high-growth economies and the policies they have implemented, see Commission on Growth and Development (2008), The Growth Report: Strategies for Sustained Growth and Inclusive Development (Washington: World Bank).
} 
the ease of obtaining construction permits, credit, electricity, and trading across borders, have a strong bearing on an economy's investment climate, ${ }^{5}$ which in turn affects the level of investment. Indeed, structural reform is often the key to raising growth rates.

\section{A. Monetary Policy}

Monetary policy has the benefit of being quick and easy to set, although it may operate with a long lag. Monetary policy can be particularly effective at slowing inflation, particularly where inflation is believed to be closely related to the rate of monetary growth. By using its policy instrument to raise interest rates, the monetary authorities can reduce inflation by curbing aggregate demand, either through reducing the volume of loans (which decreases production, sales, employment, and income), reducing asset prices (which cuts spending, since people feel poorer when their net worth declines), or appreciating the exchange rate (which reduces exports). Appreciating the exchange rate also reduces inflation by cutting the price of imports in domestic currency. Although in the long run expanding the money supply can be expected only to raise prices, in the short run, where the authorities have credibility and the economy is operating below potential output, using the policy instrument to relax monetary conditions can boost economic activity by reducing interest rates, raising asset prices, and depreciating the exchange rate.

Where monetary policy has scope to operate - in economies where most transactions take place in domestic currency and the monetary authority is not a currency board or part of a broader currency union - the process of monetary policy depends on the following issues:

\section{Toward which objective is policy focused? Monetary policy can focus} on achieving price stability, achieving a targeted exchange rate, or attaining a growth objective, such as a particular rate of economic growth or a certain level of employment or unemployment rate. Pursuing more than one objective at once is very difficult, since separate policy instruments are needed to attain each objective and one policy instrument — usually open

\footnotetext{
${ }^{5}$ For details, see the World Bank's “Doing Business” website, www.doingbusiness.org.
} 
market operations (buying and selling government securities or central bank bills, including "repurchase" and "reverse repurchase" operations) generally dominates monetary policy. The laws governing the monetary authorities differ across countries, so different countries pursue different objectives. Some target the exchange rate, while others focus mainly on attaining price stability. A few countries, such as the United States, prescribe multiple objectives for their monetary authority, allowing the authority to shift between focusing on price stability and focusing on attaining high employment or a high growth rate, depending on conditions in the economy.

\section{Which monetary framework is used? Countries can choose among} several frameworks in conducting monetary policy. Some target the growth rate of a monetary aggregate, such as broad money (M2 or M3). A few, such as the United States during the decade or so after World War II, target a certain level of market interest rates. More than 30 countries have adopted a framework called inflation targeting, in which monetary policy instruments are used to attain a forecast rate of inflation at some point in the future. ${ }^{6}$ Implementing inflation targeting requires countries to have a reasonable model linking changes in their policy instrument to forecast rates of inflation. They must also announce their inflation targets, publish the proceedings of monetary policy deliberations, and be capable of committing to their targets by avoiding "fiscal dominance" (having large fiscal deficits that dictate the stance of monetary policy).

\section{Which instrument is used to conduct monetary policy? Most coun-} tries today use indirect instruments, in particular open market operations, to conduct monetary policy. Indirect instruments have the advantage of providing a market solution to expanding or contracting the monetary base, because the desired change in the policy rate can be achieved by interacting with only those banks that wish to buy securities from the monetary authority (thereby reducing reserves and raising interest rates) or sell securities to the monetary authority (thereby adding reserves and

\footnotetext{
${ }^{6}$ See Jawan, S. (2012), "Inflation Targeting: Holding the Line," Finance and Development. Available at: http://www.imf.org/external/pubs/ft/fandd/basics/target.htm. Accessed July 16, 2017.
} 
lowering interest rates). In the past, more countries used direct instruments, such as establishing interest rate ceilings or ceilings on credit for each bank. Direct instruments typically proved less efficient than indirect instruments, because they constrained all banks, regardless of their lending position or extent of excess reserves.

Effective monetary policy ordinarily requires that the monetary authority be perceived as being independent, i.e., capable of pursuing its policy objective without requiring government approval. Under inflation targeting, some countries require the monetary authority and government jointly to agree on a targeted rate of inflation. Once the objective is set, however, the monetary authority should be free to use its policy instruments to achieve the objective without government interference.

\section{B. Fiscal Policy}

Fiscal policy, which usually takes longer to establish than monetary policy, should be well coordinated with monetary policy and aim at attaining potential output, meaning maximum employment consistent with relative price stability. Fiscal policy should also aim at attaining public debt sustainability: keeping the ratio of public debt to GDP at a low to moderate level, generally not exceeding 40-50 percent of GDP (the level at which many developing and emerging market economies have begun to experience defaults). Countries in the Euro zone have adopted 60 percent of GDP as the ceiling for public debt under the Maastricht Treaty, although countries have been allowed to exceed the limit under extenuating circumstances, such as those arising from the Financial Crisis of 2007-2009. In several advanced economies, public debt has exceeded 100 percent of GDP (e.g., the United States, Japan), and governments are struggling with how to reduce the debt ratio to a more sustainable level.

Most economies aiming to curb inflation or reduce the deficit in the current account of the balance of payments make tightening fiscal policy — reducing the government's budget deficit — part of the policy response. In many economies cutting expenditure is a key part of tightening fiscal policy. Economists usually advocate cutting so-called "unproductive" expenditure - outlays whose benefits are small relative to their costs. However, political concerns often lead economies to sacrifice valuable spending, such as outlays for operations and maintenance, rather than 
reducing public employment, cutting subsidies, or scaling back inefficient but politically useful capital projects. In some economies, fiscal consolidation also includes measures to raise revenues. Such measures are particularly valuable in countries where the ratio of revenues to GDP is very low — under 15 percent — and the government has difficulty finding enough revenue to fund basic services, such as public education and the provision of infrastructure. Although revenue raising measures usually involve increasing taxes, in some economies efforts to raise non-tax revenues, for example, by making state enterprises more efficient and profitable, can be useful. Measures to improve tax administration and increase compliance with the law can also help, although it is often difficult estimating how much revenue such measures can generate.

\section{Exchange Rate Policy}

Exchange rate policy should be used to promote competitiveness and a sustainable external current account balance, one in which any deficit is easily financed by assured capital inflows that keep the ratio of external debt to GDP modest (preferably below 40 percent), with a low ratio of debt service (principal and interest) to exports of goods and services (ideally less than 10-12 percent). If the authorities choose to fix the exchange rate, the rate should be market clearing, avoiding any incentives to create a parallel market that can distort activity and encourage corruption. To judge competitiveness, the authorities should assess the real effective exchange rate against a broad set of the economy's trading partners. Signs that a currency may be over-valued or under-valued include (1) a large and noticeable parallel market in foreign exchange; (2) a large and persistent current account deficit or surplus; and (3) a large and continuing real appreciation or depreciation in the exchange rate. The IMF now uses a method called "External Balance Assessment" (EBA), which relies on regression-based analyses to determine whether an exchange rate is overor under-valued, to assess the appropriateness of the exchange rate. ${ }^{7}$

\footnotetext{
${ }^{7}$ For details, see Phillips, S., and others (2013), "External Balance Assessment (EBA) Methodology,' IMF Working Paper 13/272 (Washington: December). Available at: http:// www.imf.org/external/pubs/ft/wp/2013/wp13272.pdf. Accessed July 16, 2017. Previously the IMF used a different approach, the so-called (Consultative Group on Exchange Rate Issues) "CGER" methodology, which employed three different methods — the
} 
The choice of exchange rate regime is a key issue for exchange rate policy. Regimes vary along a spectrum from so-called "hard fixed" regimes, involving membership in a currency union (such as the Euro zone) or creation of a currency board (where currency creation is linked to the level of foreign reserves) to floating exchange rate regimes, whether managed or freely floating. In the middle are so-called intermediate regimes, such as a managed crawl (where the exchange rate appreciates or depreciates at a set pace against a reference currency or set of currencies), floating within bands (where the exchange rate can move inside certain limits), or an adjustable peg (where the currency is fixed against a reference currency but can adjust if the authorities choose or conditions warrant - the system in effect for most advanced economies between 1945 and 1973). Small economies with a single, dominant trading partner (such as Bhutan, Nepal, or some of the Pacific Islands) may find it useful to peg their currencies to that of the trading partner. However, they need to monitor their currencies, to avoid a steady real appreciation (or depreciation) that could make the existing peg unsustainable. Economies with a history of high inflation sometimes find it useful to peg to the currency of a major trading partner with low inflation, such as the Euro zone. Again, such a peg works only if the economy keeps domestic inflation in check, to prevent the currency from becoming seriously over-valued. Economies adopting an inflation targeting regime typically adopt a floating exchange rate, to allow an independent monetary policy and open capital account (few restrictions on capital movements).

\section{Price Adjustment Issues}

Many economies fix the prices of critical goods and services, such as petroleum, electricity, or certain food items, to curb the power of monopolies or try to preserve the purchasing power of consumers. While price

macroeconomic balance, equilibrium real exchange rate, and external sustainability approaches - to assess the appropriateness of the real exchange rate. Under the CGER methodology, a currency would typically be labeled over- or under-valued if all three methods pointed in the same direction. For more information, see Lee, Jaewoo, and others (2008), Exchange Rate Assessments: CGER Methodologies, Occasional Paper 261 (Washington, DC: International Monetary Fund, April). 
ceilings are a well-established part of regulating monopolies, efforts to limit prices of other goods can create difficulties when the prices differ substantially from those that would prevail in free markets. Keeping prices below market-clearing levels can lead to shortages, as firms reduce production while consumers seek higher purchases. In some cases, price ceilings lead to high imports. In others, setting low prices for crops may cause farmers to avoid selling to state marketing boards and even smuggle goods outside the country, as in Ghana during the early 1980s. Pricing the output of state enterprises below cost-recovery levels can create losses, requiring the government budget to provide transfers and leading firms to borrow heavily from the banking system. Alternatively, firms may raise prices for other goods, establishing a complex pattern of cross-subsidization that leads to an inefficient allocation of resources. For all these reasons, governments should think carefully about setting prices below costs.

Interest rates also raise important pricing issues, since the rate of interest represents the price of borrowing or the reward for depositing money. Setting interest rates below the perceived rate of inflation, which creates negative real rates, discourages saving while encouraging borrowing, exacerbating the imbalance between the demand and supply of funds for lending. Thus, economies should avoid allowing interest rates to become negative in real terms, particularly for deposits.

Finally, the real exchange rate itself represents an important price in the economy. An overvalued exchange rate discourages exports while encouraging imports. Thus, it helps weaken the current account balance. However, an undervalued exchange rate raises the price of imports in domestic currency, thereby adding to inflation. Thus, economies do better when the real exchange rate is at an appropriate level - neither overvalued nor under-valued.

\section{E. Structural Policies}

Structural policies play an important role in supporting monetary, fiscal, and exchange rate policies and contribute importantly to an economy's investment climate. At any one time, certain structural issues are particularly important in an economy. For example, during the 1990s, in many eastern European countries, privatization, state enterprise reform, price 
liberalization, and rationalizing subsidies were critical steps in the transition from central planning to a market economy. In other countries, such as Indonesia, eliminating monopolies and strengthening competition among market participants were important. Many economies at all income levels have grappled with financial sector reform. Others have implemented reforms in tax administration, budgeting, and public expenditure management. External sector reforms, including trade liberalization and, where appropriate (usually only after strengthening the financial sector, with adequate regulation and supervision), capital account liberalization, can also be valuable. Better corporate and public sector governance, including a more efficient judicial and legal system and more transparent and effective delivery of government services, can play a critical role in improving the investment climate. Combatting money-laundering and terrorist financing is important for strengthening the rule of law. Finally, research shows that reducing corruption can boost investment and raise a country's growth rate. ${ }^{8}$ Addressing whichever of these issues is problematic can be important for economic adjustment and promoting growth.

\section{SUMMARY AND CONCLUSIONS}

Macroeconomic analysis is the study of an economy's main components: the accounts used to measure performance, key performance indicators, and the main policies driving the economy. For the purposes of analysis, the economy can be subdivided into four main sectors: the real sector, whose performance is measured by the national accounts; the external sector, where performance is measured by the balance of payments and data on external debt; the fiscal sector, whose outcome is measured by budget and debt data on all levels of government, possibly augmented by the consolidated accounts of the pubic (state-owned) enterprises; and the monetary sector, whose activities are usually summarized in the monetary survey, which combines the accounts of the

\footnotetext{
${ }^{8}$ Mauro has estimated that a one standard deviation reduction in corruption, based on the "Business International" index (subsequently acquired by the Economist Intelligence Unit), is associated with increases of 0.5 percent in a country's real growth rate and 5 percentage points in its ratio of investment to GDP. See Mauro, P. (1995), "Corruption and Growth," Quarterly Journal of Economics, Vol. 110, No. 3, pp. 681-712 (August).
} 
monetary authority and the consolidated deposit money (commercial) banks. The four sectors are related in many ways, and activities originating in one sector generally affect all other sectors.

An economy's performance can be assessed by analyzing developments in key indicators drawn from the accounts of the real, external, fiscal, and monetary sectors. Key indicators from the real sector include the growth rate of real GDP, the ratios of national savings and total investment to GDP, and the percentage changes in the consumer price index, the GDP deflator, and possibly other price indices. Important indicators from the external sector include the ratio of the current account balance to GDP, the size of the overall balance in the balance of payments, trends in the real effective exchange rate, and the ratios of external debt to GDP, debt service (principal plus interest) to exports of goods and services, and gross reserves to short-term debt service. Useful indicators from the fiscal sector include the ratios of revenue, expenditure, the overall fiscal balance, and total government debt (foreign plus domestic) to GDP. Important monetary and financial indicators include the growth rate of broad money, nominal and real interest rates on loans and deposits, the percentage of nonperforming loans, indices of housing and asset prices (to test for asset price "bubbles"), and measures of corporate and household indebtedness.

Most economies strive for high growth, low inflation, and a sustainable balance of payments, often accompanied by efforts to reduce poverty, preserve the environment, and limit income inequality. Governments try to attain these objectives using monetary, fiscal, and exchange rate policy, along with structural policies in such areas as financial sector regulation, trade and competition policy, and measures to strengthen company and public sector governance. The careful use of structural policies can promote stabilization and improve the investment climate, thereby supporting economic growth. 